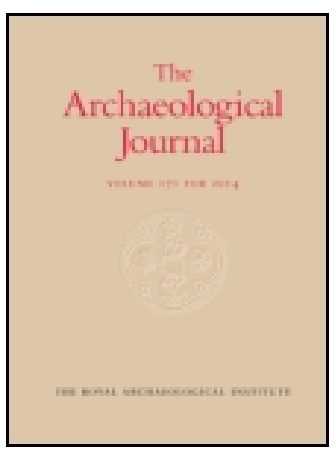

Archaeological Journal

\title{
Notices of Archaeological publications
}

\author{
J. B. S. \& J. N.
}

To cite this article: J. B. S. \& J. N. (1879) Notices of Archaeological publications, Archaeological Journal, 36:1, 105-115, DOI: 10.1080/00665983.1879.10851903

To link to this article: http://dx.doi.org/10.1080/00665983.1879.10851903

曲 Published online: 14 Jul 2014.

Submit your article to this journal 준

Q View related articles $\longleftarrow$ 


\section{Rotices of Xrcharological Jublications.}

HENRY VII, PRINCE ARTHUR, AND CARDINAL MORTON. From a group representing the Adoration of the 'Three Kings un the Chancel Screen of Plymtree Church in the County of Devon. With an Appendix containing a notice of "Nicholas Monk, Rector of Plymtree, "John Land," \&c. London : Printed for T. Mozley, Rector of Plymtree, \&\&.

In the opening lines of his book Mr. Mozley puts into the mouth of a reader the question "Where is Plymtree?" Henceforth such a question, at all events among Archeologists, will be absurd. Plymtree has found its vates sacer, and, since this book was published, has probably been enquired about and discussed more than any village of its (very small) size in the land; surely no edition of fifty copies was ever diffused so widely, or gave rise to so many gossiping conversations.

The work deals with the biographies of three persons, all more or less connectel with the Parish of Plymtree, and may well be entitled "Historical Memorials of Plymtree" after the fashion of the well-known "Historical Memorials of Canterbury"; which, though setting out from narrow topographical hasis, extend by digressions far out of sight of the starting point.

The first of the Memorials is concerned with a group of personages who, at first sight, would appear to be strangely out of place in a Devonshire village so secluded as to be, even at the present day, remote from highways. King Henry VII, Arthur his son, and Cardinal Morton his astute chancellor! Did these ever visit, or even hear of, Plymtree ? By what literary artifice can the actors be brought to the front of the scene? With a dexterity which excites an amused surprise Mr. Mozley has got over the difficulty, and on a small material foundation furnished by the pictures on the screen of his parish church, he has built up a history in which the three above-namel personages are the principal figures.

Devonshire churches, as archreologists know, abound in well preserved, and often handsomely painted, rood-screens; and among them Plymtree takes a foremost place in this particular, being enriched by paintings of thirty-four full length figures of saints and other personages appropriate to the place. In the author's worls: "The chief ornament (of the church) is a magnificent screen, stretching right across the interior, ancl separating the chancel and chancel aisle, or chantry, from the nave and its aisle. This is profusely carved, painted, and gilded . . . . There are thirty-four panels, constituting the solic part of the screen below the open work, and unfortumately below the level of the eye. It is not easy to make a probable conjecture as to the exact clate of either the screen or the pictures ; but as the Reformation was coming on rapidly by the year 1525 , the date of the latest picture could hardly be later than that; 


\section{NOTICES OF ARCHAEOLOGICAI PUBLICATIONS.}

while it is possible, and not even improbable, that the group to which this notice is prefixed (in the folio copy) was done in the very lifetime of the persons represented."

The anthor then goes on to give his reasons for believing that of the three figures in the group of the "Aloration of the Kings," the first, clad in rerl, may represent Cinrlinal Norton; the second, a youth, Prince Arthur; and the third, a crowned king, Henry VII. After a not very laborious attempt to prove his identification of the Magi, Mr. Mozley puts together from trustworthy authorities, a vivid account of Cardinal IIorton himself and of the times in which he lived. Due allowance, in the matter of likeness, being mate for the fact that the paintings were executed by a lecorator, and not by a portrait painter, we think that the author has made out a fair "case" At all events he has brought together a large quantity of interesting and trustworthy information about an eminent man, who was born within a day's ride of Plymtree; in whose days Plymtree Church was re-built and decorated; and whose skill in state craft was so generally recognised that Shakespere makes Richard III, Morton's political enemy, hearing that-

exclaim-

"Morton is fled to Richmond," \&c.,

" Ely with Richmond troubles me more near

Than Buckingham with his rash levied strength."

The second subject in these "Memorials of Plymtree" is based upon a local foundation far broader than the first. In this case a Rector-not an absentee or honorary-but an active, resident Rector of Plymtree, played an essential part in one of the greatest clramas of English history. Nicholas Monk, the Rector in question, was brother to George Monk, first, general of the Commonwealth, then, restorer of the Stuart lynasty, and Duke of Albemarle. More than this the rector was a staunch cavalier, and, masking a natural shrewdness by a seeming simplicity, he was the ambassador who, with success, conducted the negotiations between the king at the Hague and the general in Scotland. All the worthy deeds of his predecessor the present rector of Plymtree tells most pleasantly, and, although this need hardly be written, learnedly. Nicholas Monk was, however, not a mere political go-between; his biographer in summing up his character as a parish clergyman, writes :

"In the year 1643 the subject of this notice was serving the Church as resident curate. He was thus connected with Plymtree for more than nineteen years, . . . and his name appears in the parish book as contributing to a sort of voluntary (poor) rate till a year or two before the restoration. It is prominent also in the list of 'Gifts and Benefactors to the Poor of Plymtree,' put up early last century, if not earlier."

A third Plymtree worthy (as old Fuller would have used the word) was John Land, the younger son of a good yeoman family in the parish, who, leaving his home before the middle of the 17 th century, went to London, became a prosperons goldsmith, and, while yet a bachelor, retired from business, disposing of his goodwoill and shop, which adjoined Temple Bar on the city side, to Mr. Blanchard, also a goldsmith. Mr. Blanchard in his turn made way for Sir Francis Child and his clerk, Mr. Rogers, by whose successors the business, still known as "Child's Bank," has been carried on to the present day.

Lanl's will, which Mr. Mozley recites at length from a copy in the 
parish chest, proves that in the midst of his prosperity in London he retained his affection for his Devonshire home, and for his kindred to whom he bequeathed many legacies. He left a hundred pounds to be placel at interest for the benefit of the poor of his native parish ; he provided a crimson velvet pulpit cloth embroidered with gold for the church in which it still remains; but above all he directed his executors to sell-

"My two silver tankarls, two silver plates, a silver guilt salver, candle cupp and porringer, a silver boate and taster, a little silver box, two dozen of silver spoones, and one dozen of silver guilt spoones, and all my plate whatsoever. And also my large golde seale, my large plaine golde ring, three cliamond rings, and eight other mourning and hair rings. And the money to be raised thereby I order to be laid out by my executors in the purchase of plate for the communion table of the chunch of the said parish of Plymtree." \&c.

It will be seen from this notice that Mr. Mozley, in common with a happily increasing number of the clergy, has recognized the fact that in his parish chest is to be found the Record Office of his parish ; and also that written documents are not the only materials for writing the history of the place uncler his charge; but that the architecture and decorations of his church are really to contribute their share to the tale of by-yone days. Having recognised this, he has successfully employed his practised pen in uttering to the world the story which he has compiled.

So much for the matter of this book ; of the manner of its prorluction we can only speak with admiration. In the first place it is lavishly illustrated, as we shall explain more at length presently, but in the second there is a peculiarity of the author's own invention. It is this : every one who is so fortunate as to receive this book has tuo copies! One a large folio containing the coloured plates, and the complete text printed in double column, with ample margin; and also an octavo hand-copy of the text, merely illustrated with outlines of the plates of the folio. Of the liberality of this duplex manner of issuing a book which is to be given away, we neel not speak, the fact is eloquent; whilst of the convenience of the invention of an octavo for realing, and a folio for reference, every reacler must be a competent judge.

We will now say a few worls upon what we have previously remarked as the important part of the volume-the drawings. There are four colourecl plates, each measuring $15 \frac{1}{2}$ in. by $6 \frac{1}{4}$ in.- -fac-similes of the paintings on the screen. We have compared these with the original paintings, and we are happy to recognise the skill and ability of Messrs. M. and $\mathrm{N}$. Hanhart, who have reproduced the paintings by chromolithography in a highly successful manner. We are more especially glacl to say this, for in so many books the chromo-lithographs lose the mellowness, the depth, and the feeling of the old work. The toue and character of oil colour are here well preserved, and it requires a keen eye to cliscover a slight defect. The expression on the face of the Virgin in the original is not particularly happy, but yet quiet and placid. In the copy (plate 1) the mouth is distorted, and the profiled outline is not in good drawing ; these, together with the slight defect in the right eye, produce an unpleasantness in the Virgin's face, which we are spared in the original. The expression of the child is "well canght."

We turn with unqualified praise to the figures called Prince Arthur 


\section{E NOTICES OF ARCHALOLOGICAL PUBLICATIONS.}

and Henry VII. Here the artist having bestowed more care, has worked with singular success. The gradations from the high lights upon the crown, \&c. to the deep background are carefully given, and the chromolithographs present the same richness of tone as the originals.

The original paintings are on oak panels of about half an inch thick. They have a certain "old" appearance owing to the unevenness of the surface of the oak, and a few occasional chips-but generally they are in excellent preservation-somewhat hicklen by successive coatings of common varuish.

One word more-we cannot impress too strongly the necessity that, wherever possible, copies of old paintings should be of the real size, in fact facsimiles in every way. It is only by doing this that we can hope to obtain the character and feeling of the original artist. $\mathrm{We}$ are too liable to forget that in reprolucing for publication the works of past ages, we are not to attempt to make pretty drawings, but exact cojies, line for line, of the originals - not as we think they should be, but exactly as they are. We are then doing good service, and handing on, for the stuly of future ages, many representations of the various schools of art, which are rapidly disilppearing. Mr. Mozley has anticipated our icleas, and it is owing to his chawings being fac-similes that they have proved so successful and valuable. We should like to see the sime loving care bestowed upon illustrations of the elaborate wool-carvings of the bench encls with which the whole of the church is filled.

J. B. S. AND J. N.

A KEY TO DONESDAY, shewing the method and exactitude of its mensuration, and the precise meaning of its usual formulie; the subject being specially exemplified by an analysis and digest of the Dorset Survey. By the Rev. R. W. EYTON, M.s., late Rector of Ryton, and Author of "Antiquities of Shropshire." London: Taylor \& Co. Dorchester: James Foster.

In our last number we had the pleasure of noticing a work by the learned historian of Shropshire, and it is now our privilege to introluce to our reaclers another volume by the same anthor.

It was justly observed by the late Sir Henry Ellis in 1833, in the preface to his valuable Introduction to the Domesclay Book (to the diligent and careful study of which he had devoted twenty years), that "Domesclay Book is a mine of information which has not yet been sufficiently wronght. Illustrations of the most important and most certain kind upon our ancient institutions, terriers and tenures of lands, are still to be drawn from it, and its metal camnot be exluausted by the perseverance of any single labourer."

In much of this spirit has MIx. Eyton entered upon the study of the Domesday of Dorset. He says, "Domeslay is its own best interpreter, and those who would understand Domesclay thoroughly must get their information from Domesclay itself." In the work before us he fulfilled the promise of his lengthy title. In the preface lie fully states his objects to be: "to cnable the inquirer to ascertain with more or less precision the Domesclay antecedent of every locality in Dorset; to distinguish and compare the various classes into which the property was then divided, whether a Borough, a Port of Commerce, a Vill, a Manol, a Farm, a Moor, or a Forest; to shew the arcal extent of every such estate, 
or, at least, to shew how far such extent may be determined from the text of Domesclay; - of all occupied territory, whether plough land or meadow land, or pasture, or wood land, to shew the ratio of its culture or its uses; to determine the relative wealth of such estate, whether resulting from inherent capabilities, inclustrial care, or external adjuncts ;and coincidently, to collect and review the hints which Domesday supplies as to the comparative numbers and conclition of an almost exclusively agrarian population."

It will thus be seen that the scope of Mr. Eyton's inquiry is very widle, but though extensive, his investigation has been most complete and exhaustive, leaving little to be clone by future students as far as the county of Dorset is concemed; and, moreover, he has thrown a vast amount of achlitional light upon most of the obscurities with which the great record of which he treats is clonded, not only with relation to the county of Dorset, lut also to the Surveys of other counties, especially those in the western part of England.

Mr. Eyton, in the first instance, proceeds to elucilate, in an Introductory Essay, the important questions of mensuration, technicalities, and pluraseology of the whole Survey, comparing the rules and methods by which the Dorset Conmissioners were guided with the Surveys of other counties in which the Commissioners acted upon a somewhat different process, observing that "the contrasts are often more instructive than the parallelisms." He points out that throughout the whole of the Domesday Book reference is male to two distinct systems of mensuration--(ne system, he observes, was antiquated though not obsolete; the other was that then in use; the older being based upon the Saxon Hide, which, like Iillis before him, he calls hidation.

It is umnecessary that we should enter very closely upon the question of the extent or area of a hide. It has long been admitted by all Domesclay students that neither the lidle nor the curucute were ever areal measurements, and Mr. Eyton clraws attention to the fact that the term Hide was used by the Saxons as representing the quantity of lancl, whatever its extent, which was attached to a homesteen, and because in most instances the area was just sufficient to employ and support a team of oxen the term hide and the term corucate becane convertible. Ho observes that when in the time of King Ethelred 976-1016 (it was in 1007 ) it became necessary to levy a tax to buy off the Danes, the country was sub-divided for the purpose of equal taxation, and the lide was accepted as the basis of assessment. On this occasion the lidage of the whole country was carefully examined and re-arljusted, consequently when in Domesday the term hirle is used it must be unclerstood as a term of record, and represents such a quantity of land as was cletermined to be a licle and to be gildable as a hicle by the taxation of King Ethelred or some later fiscal authority. The Domesday Commissioners of Dorset, therefore, Mr. Eyton says, got the hidation assigned to Dorset manors rather from previous record than present inquest, and that, with some slight alterations, they obtained it from the Dorset Gheld-Roll (as he writes it) made at Faster 1084.

The actual area of hides differed very widely. In Cornwall the same Commissioners who visited Dorset are found to have frequently drawn an apparent contrast between the reputed and the actual hiclage of certain manos.s. For example, the Mimor of Trogcl at the time of the surveg 


\section{NOTICES OF ArCHAEOLOGICAL PÚBLICATIONS.}

held by Osbert Bishop of Exeter, in the time of Edward the Confessor was gilded for two hides, nevertheless, the Commissioners say, there are twelve hides; and Mr. Eyton points out that this was not corrective but explanatory, shewing that Tregel, though a manor of twelve hicles, was gilded for two hicles only, ten hides being, by prescription, exempt from grild. He states that 110 such formula as this is found in the Dorset Domesclay because a non-gildable hicle in Dorset would not be called a hicle at all but a carucate. With reference to this subject it is remarked that it was a principle of the Saxon gill-laws that not only the ancient clemesnes of the crown were to be absolutely free from gild, but that the bona-fide demesnes of the Thanes, or Tenants in Capite, should also be exempted from the current gild levy, because, in respect thereto, the tenants had to render personal service. MIr. Eyton exhibits numerous instances of beneficial hidation, shewing very extensive contrasts in the area of land denominated a hide. Cornwall was particularly favoured in this respect. The Manor of Heleston, held by Earl Harold in the time of King Edward, now by the King, is rated for six and half hides of ordinary Cornish leidution, but it covered an area of more than 30,000 acres of mixed lands which, according to the hidation of Dorset, was equal at the least to forty hides, and it paid gild in the time of King Edward for only two hides. Besides the hidation thus especially privileged there existed numerous other circumstances which disturbed the uniformity of the hides, from which it would appear that hides were originally regulated in the time of King Ethelred rather by intrinsic value than area. In other instances the hidation of manors would appear to have been oreatly influenced by adventitious circumstances such as salubrity of climate, proximity to some great thoroughfare, or centre of trale, \&c., and $\mathrm{Mr}$. Eyton mentions the remarkable fact that in Dorset alone some hides are represented by at least 4000 statute acres, whilst others contain not more than eighty-four ; observing, however, that the average for the whole country would give from 230 to 240 acres. Our author accounts for the hide having obtained the repute of being an areal measure by suggesting that the most important characteristic of a Dorset manor was its quota of plough-land, and that it came to pass that the specific hide of most manors appears in numerical conjunction with a single plough-gang, or in the words of the Dorset Domesday, a terra ad. unam carucum, by which means the Dorset hide was brought into a sort of parallelism with the Dorset plough-land, and Domesday itself, he says, indicates that the word carucate implied much the same thing as the term hide, only that not having been converted into a hide, or made gildable, it remained in name a carucate. The typical carucate of Dorset, he adds, resembles the hide in that it contained a single plough-gang, combined with other territorial adjuncts; it differed from the hide in that its essence was nothing but land.

The plough-gang, or terrem at unam carucam, differed from the carucute as a part cliffers from its whole, and in the same manner did the plough-rang ciffer from the hide. In the Dorset Domesday where the number of plonghs (crivuce) proper of any given manor was equal to, or in excess of, the number of hicles there one great element in the value of such manor was its arable land, and conversely, where the number of (curuce) proper is found to be less than the reputed number of hides then the element of value which constituted the hide consisted of other advantages, such as mills, meadows, pastures, woods, \&u. 
To meet the necessities of an assessment based upon the hide in taxing estates of various value, less than a hide, it became essential to divide the hide into lesser denominations, and the terms used were so suggestive of areal measurements as to lead to, or strengthen, a misapprehension on the subject. These subdivisions were:

$$
\begin{aligned}
1 \text { Hide }=4 \text { Virgates }= & 16 \text { Forndels }=48 \text { Acres } \\
1 \text { Virgate }= & 4 \text { Ferndels }=12 \text { Acres. } \\
& 1 \text { Ferndel }=28 \text { Acres }
\end{aligned}
$$

In Dorset the gild-hide was divided into four virgates, and each virgate into twelve acres, but in Devon and Cornwall, where the gild-hide was, in many instances, of enormous extent it was necessary to introduce an intermediate denomination between the virgate and the acre, which was called a ferndel (farthing or fourth-ing), but none of these denominations were any more areal measures than was the hide. The acræ ad gheldum, as Mr. Eyton prefers to write it, was quite distinct from the measured, or Norman, acre used in stating the quantities of meadows, pastures and woods, which latter was simply the statute acre legalised afterwards by King Edward I., and continuing in use to the present time. This is proved by many examples extracted from the Domesday Book.

The term carucate Mr. Eyton considers a Norman term introduced at the Conquest, and, he supposes, was very nearly analogous to a Saxon hide; and he illustrates this conjecture by the fact that in the Fief of Strigoil (Chepstow), in Mommouthshire, which had never been conquered by the Saxons, the term hide is not used, and the carncate is expressly mentioned as a Norman measure ( $\mathrm{L}$ carucatas terre, sicut fit in Normannia). In the survey of Lincolnshire also the term hide is not used, and evidence is shewn that the carucate and the hide were corresponding quantities. But on the other hand the terra ad unam carucata, or plough-gang, was of a different character, and constituted very nearly, if not quite, an area of about 120 acres statute measure. The plough-gang also was subdivided. As the caruca, or full ox-team, consisted of eight oxen, so was the plough-gang divided into eight bovates, and the smallest quantity of arable land mentioned in the Dorset Domesday is two bovates, and this is not described as Duce bovatce terrese but Terra al duos boves. This was a fourth part of a Terra ad unam carucam, and consisted of thirty acres.

The lineal measures by which the meadows, pastures, woodlands, and wilds, were described are more definite. This system of measurement, Mr. Eyton tells us, was that then in vogue, and the Norman Commissioners chose thereby to classify the result of their own investigations as distinct from information received by evidence of others. These measures, taking the pertica or virya at $16 \frac{1}{2}$ feet, or $5 \frac{1}{2}$ yards, is thus tabulated:

Table, p. 25.

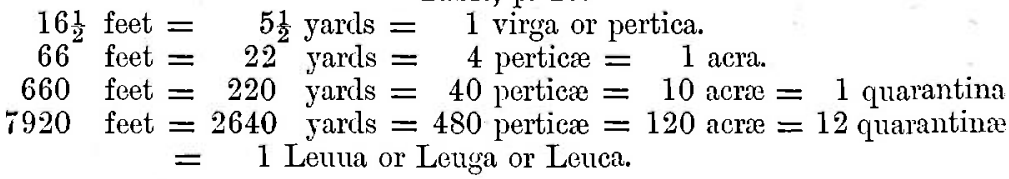

In consequence of the use made in Domesday of these lineal measures, it is very important to understand in what respects they differed from our 
present conception of measuros of length. This Mr. Eyton has clearly explained, shewing that instead of proceeding from the farling (four long) or quarantine, to the Norman league of twelve quarantines, we have adopted, as the next higher clenomination, a mile consisting of eight quarantines, and above the English mile we have the higher denomination of a league, or three English miles, which is just double the Norman leuna or leuga. Of the areal or superficial measures, he remarks that they must not be confounded with square mearures, because the Domesday measures have usually unequal sides; and discarding the measures called local, he shews that the Domestay perch consisted of $5 \frac{1}{2}$ fards, as subsequently confirmed by statute, and still remaining in use.

\section{Table, p. 30.}

Table of Areal Measurls of the Dorset Domesday, the lineal perch perch or virga being taken at $16 \frac{1}{3}$ feet or $5 \frac{1}{2}$ yarts.

$30 \frac{1}{4}$ square yards $=\quad 1$ " "pertica" or square perch.

4840 square yarls $=160$ "pertice" $=1$ areal acre.

48400 square yards $=1600$ "pertice" $=10$ areal acres $=1$ square quarantine.

580800 square yards $=19200$ "pertice" $=120$ areal acres $=12$ square quarantines $=1$ areal league.

With this table the modern system corresponds in ratio, though using different denominations.

Having treated very fully and ably of the mensuration of Domesday, our author proceeds to describe the district surveyed-its Royal Forests, its woods, its pastures, its meadows, its vineyards, of which there were two, its gardens, its orchards, and its churches and church lands-shewing the application of the measurements before described, and the probable condition at the time of the survey of each class of land.

In writing of the Domestay agrarian population of Dorset he names the several classes in the order of their degrees of freedom, and shews the conclition, respectively, of each class; leaning, we think, to a larger amount of freedom among the unfree than that which we had been accustomed to hold. He also shews the conclition of the inhabitants of towns, the burgesses and the industrial classes, and treats of the farming stock, the values of lands and rents, \&c., and brings before the reader a large array of illustrations, collected from Domesday itself, proving the theories he had advanced.

Having described the four Dorset Boroughs, and exhibited Tables of Dorset Landholders, with special notices of individuals, Mr. Eyton proceeds to treat of the lands held by the king, distinguishing the ancient demesnes of the crown from those which had fallen into his hands by escheat. The former were free from gild, but the latter, though held by the king, did not cease to be Hundredal and taxable. These chapters are particularly interesting and instructive. He compares the Inquisitio Gildi of 1084 with the Survey of 1086 , and has appended rery copious statistical tables, exhibiting the results of these enquiries.

Returning again to the question of statistics, it appears that the number of the arlult male population of Dorset as deduced from the record of 1086 , was about 9,000 ; whilst by the census of 1871 , the total number of the whole male population of the county was 95,616. Assuming that 50,616 of these were chillren, the remaining 45,000 is only a five-fold 
increase, or 500 per cent., in the period of 800 years. And Mr. Eyton points out that though in these eight centuries the increase of population has been 500 per cent, the same period has been marked by an increase of about 3,500 per cent. in the denominational price of corn and cereals ; by an increase of about 6,000 per cent. in the denominational price of live stock ; and by an increase of 24,000 per cent. in the demominational price, or rent, of land.

He estimates the average value of land in Dorset in 1086 as $1 \frac{1}{2} \mathrm{~d}$. per acre, and the present ralue as averaging $£ 11 \mathrm{~s}$. Od. per acre. IIe uses the term denominational adviselly, for as to real value there is a further question. The real value of a thing is the price for which it will sell, and the real value of money is the quantity of commodity a given amount will purchase. $\Lambda$ shilling in 1086 would pay the rent of eleven and half acres of land, would suffice to purchase perhaps two store sheep, or a quarter of mixed corn. In one case it was as valuable as 240 shillings of our money, in other cases it would purchase as much produce as $35 \mathrm{~s}$. or $60 \mathrm{~s}$. But then arises the question. Why has land increased so much more in real as woll as denominational value than the products of land in real value? In answer, Mr. Eyton states " that the increase in the value of land has been causerl by forces about five times as great as those which have operated upon prouluce. One fifth only of such forces consists in the marketable incrense per head, or per quarter, of land products. The remaining four-fifths of such forces consist in the cireumstance that land has been brought to produce from four-fold to twenty-fold as much in bulk, or quantity, as it did at the date of Domesday."

One other subject clemands a brief notice, viz., the parties by whom the Domesday territory of Dorset were held. Mr. Eyton has divided the whole area of the county into 265 parts, of which, he says, there will have belonged-

"To the King in demesne or by lapse, or escheat nearly $36 \frac{1}{2}$ such parts To the Bishop of Salisbury and other Ecclesiastical persons or bodies

102 such parts. To Earls, Barons, and the greater Feudalists $\ldots$ To the lesser Feudalists, or Franci, to the Kings' 98 such parts. Thanes, to the Kings' Serjeants, to the four Boroughs of Dorset, and to a few unclassified land owners

about $28 \frac{1}{2}$ such parts," and he remarks that, "the great and marvellous feature in this disposition of the Dorset lands is, that the Church, with her vassals and dependents, enjoyed more than a third of the whole county, and that her patrimony was greater than that of all the barons and greater Feudalists combined."

OLD ENGLISH PLATE, Ecclesiastical, Decorative, and Domestic; its Makers and Marks, with improved Tables of the date-letters used in England, Scotland and Ireland, founded upon the Papers and Tables of C. Octavius S. Morgan, F.R.s., F.s.A. By WrLfred JoskPH CRIPPS, M.A., Barrister at Law. London: John Murray, 1878.

Most of our readers will be well acquainted with the treatises on Assay marks, and with the valuable tables used at Goldsmith's Hall, London, by Mr. Octavius Morgan, printed in the Joumals of the Institute for 


\section{NOTICES OE ARGHAEOLOGICAL PUBLICATIONS.}

1852 and $1853,{ }^{1}$ which, with the exception of a slender attempt made some years previously, was the first effort towards the identification of the date of Old English Plate. Soon afterwards, Mr. IV. Chaffers published a work on the same subject, in which he not only improved Mr. Morgan's Tables by adling the forms of the shields in which the clate-letters were jlaced, which Mr. Morgan had not thought it necessary to give, but appended also arditional tables of marks used at the assay offices at Edinburgh, Dublin, and Exeter. These tables continued the standard authorities in the sturly of this very interesting. sulvject until the publication of the very valuable work at the heal of this notice, which greatly eclipses its predecessors. Mr. Cripp's work is based upon Mr. Morgan's tables, from which gentleman he has, in its preparation, received very valuable assistance, which in the fullest and nost graceful terms he acknowledges. The Assay Tables in the work before us have been made more complete, and tables of the York, Norwich, and other local assay oftices adiled; moreover, Mr. Cripps has appended very extensive tables of makers'-mark, which are very valuable to the sturlent as enabling him, in many instances, not only to establish the yoar in which any particular piece of plate was male, but also to ilentify the master workman by whom it was manufactured.

It is not only with respect to the tables here alluded to that MIr. Cripps excels. He has made a very careful study of the whole subject of Old Fnglish plate, and his disquisitions on the various marks and the several classes of plate, will be read with much interest and profit. Unfortunately articles of such great intrinsic value, and so easily convertible, as plate, are specially liable to destruction, and consequently we have to lament the loss of most of the magnificent objects of art-workmanship and value with which the beaufets of our knights and nobles and our religious houses, as well as the altars of our churches, were in medizeval times enricherl. Into the subject of these losses Mr. Cripps fully enters, especially with respect to the destruction of the ancient chureh plate in the sixteenth and subsequent centuries. Space will not permit us to enter upon this subject further than to remark that all the ancient chalices and patens known now to exist, may be counted on the fingers. There is a fine chalice and paten, silver gilt and enamelled, at Nettlecomb in Somerset, exhibited at the Institute and at the Society of Antiquaries, by Mr. Morgan in 1869, a description of which by him is published in the Archeroloyia (vol. xl, p. 405), beautifully illustrated of the full size in chromo-lithography. But there are no articles of antient domestic plate of greater beauty and interest than the old mazers. Being made chiefly of wood, usually taken from the knotted knarles of the maple and beautifully polished, though enriched with silver mountings, their intrinsic value did not afford so strong a temptation to their clestruction as if they were wholly composed of the precious metal.

Many of the ancient mazers continue in existence of various sizes, some as much as a foot in diameter and some very small. They are all ornamented in much the same style, having a rim of silver which, rising above the erlge of the bowl, increased its depth, underneath which was a band on which an inscription is usually engraved. Mr. Cripps has given illustration of several examples, but there are none finer or more

1 Vols. ix and $x$. 


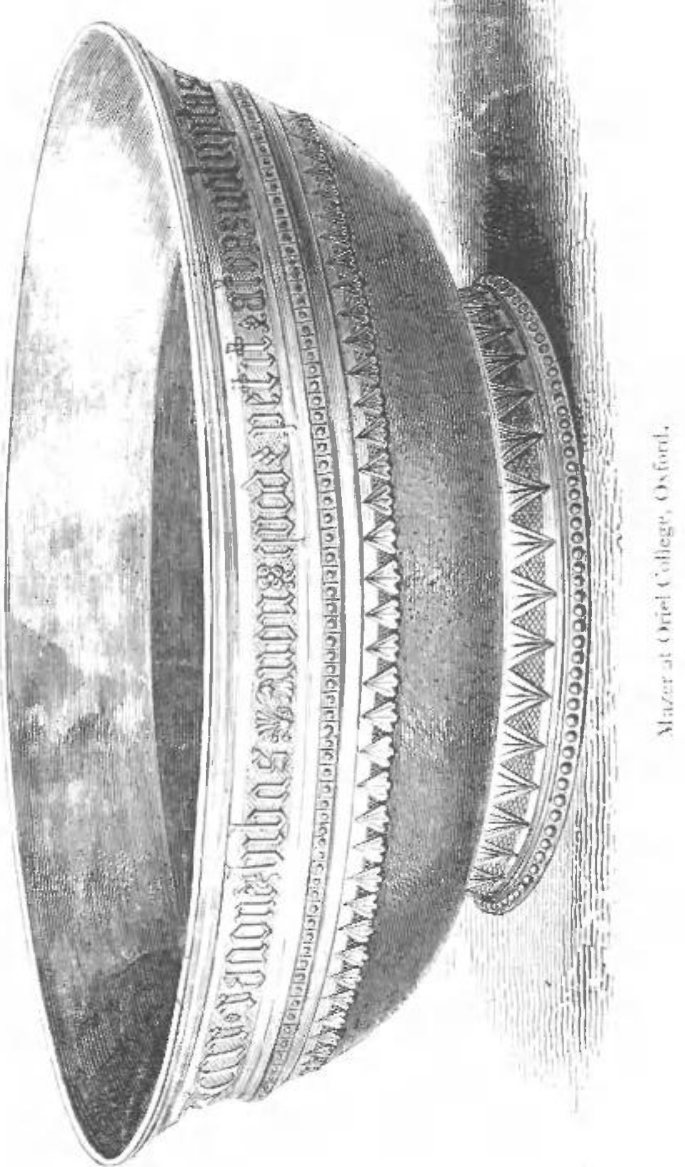


beautiful than one preserved at Oriel College, Oxford, of the date (circa 1470), which was given to the college by Bishop Carpenter about the time it was made. A beautiful woodcut of it was prepared by the late Mr. Albert Way, but in consequence of his lamented death it was never used until a cast of it was lent to Mr. Cripps for his valuable work, and it is now here introduced. It is eight inches in diameter and two and half inches in depth, and on the band around the rim is the following inscription in Gothic letters-

Eír racione bibas non quod petít atra boluptas Sic caro casta datur bls língue suppeoitatur.

PALGRAVE FAMILY MEMORIALS, edited by Charles John Palmer and Stephen Tucker (Rouge Croix), Norwich : Printed by Miller and Leavins. (For private distribution only.) $18 \% 8$.

Family memorials, though of course chiefly of interest to the families immediately concerned, are of considerable general value when they are carefully and conscientionsly prepared. This appears to be the case with the work before us. Indeed the name on the title page of one of the most active and able of our Officers of Arms is a sufficient guarantee that the genealogy and heraldry have been carefully scrutinized.

The genealogy of the several houses of this name are carefully traced. They do not all seem to have descended from the same ancestor, and it is only those experienced in the work who can conceive the difficulty in such circumstances of identifying those of the same name and fixing them in their proper places in the respective pedigrees. The editors in this case appear to have been successful in their labours. The genealogy is well supported by abstracts of wills, extracts from parish registers, \&c. The most remarkable man of the family would appear to have been the late Sir Francis Palgrave, deputy keeper of the Public Records, and the learned historian of "The Rise and Progress of the English Commonwealth," the "History of Normandy and Englaud," \&c. His original name was Cohen, but, having married Elizabeth, one of the daughters of Dawson Turner by Mary Palgrave, daughter and one of the coheirs of William Palgrave, of Coltishall, he upon his marriage, in 1825, with the assent of William Palgrave, then the head of the family, by Royal license, took the name of Palgrave, and was granted a Coat of Arms. 